\title{
FAKTOR-FAKTOR DALAM PENGEMBANGAN SARANA DAN PRASARANA DI PESISIR BARAT KOTA TARAKAN
}

\section{FACTORS IN THE DEVELOPMENT OF FACILITIES AND INFRASTRUCTURE IN WEST COAST OF TARAKAN CITY}

\author{
Iif Ahmad Syarifi'), Eko Prihartanto²), Efraim Bavo Priyana3) \\ 1),2) Jurusan Teknik Sipil, Fakultas Teknik, Universitas Borneo Tarakan \\ 3) Program Studi Pariwisata, Jurusan Manajemen, Universitas Terbuka \\ Email: ${ }^{1}$ iifahmad@borneo.ac.id, ${ }^{2}$ eko_prihartanto@borneo.ac.id, ${ }^{3}$ efraimbavo@ecampus.ut.ac.id
}

\begin{abstract}
ABSTRAK
Pengembangan sarana dan prasarana di Kota Tarakan, menjadikan daya tarik masyarakat untuk bermukim khususnya di wilayah pesisir. Dimana wilayah pesisir menjadi tempat bermukim yang memiliki faktor-faktor yang menarik untuk dikaji. Prasarana dan sarana diwilayah tersebut akan diteliti untuk dikembangkan sehingga lebih dapat mensejahterakan masyarakat dalam memperoleh fasilitas dari pemerintah Kota Tarakan. Objek penelitian ini adalah kelurahan Selumit pantai yang berada di pesisir barat Kota Tarakan propinsi Kalimantan Utara, dengan responden sebanyak 100 orang dan menggunakan metode Deskriptif untuk membahas data-data yang berhubungan dengan keadaan sebenarnya. Hasil yang diperoleh didapat 8 faktor yang terdapat dalam pengembangan sarana dan prasarana dengan 16 variabel di wilayah pesisir barat kota Tarakan.
\end{abstract}

\section{Kata Kunci: Fasilitas, Pesisir, Prasarana, Sarana}

\begin{abstract}
The development of facilities and infrastructure in of the Tarakan City has attracted people to live, especially in coastal areas. Where the coastal area is a place of residence which has interesting factors to study. Infrastructure and facilities in the area will be researched to be developed so that the community will be more prosperous in obtaining facilities from the Tarakan City government. The object of this study is the Selumit Pantai village on the west coast of Tarakan City, North Kalimantan Province, with 100 respondents and using descriptive methods to discuss data related to the actual situation. The results obtained obtained 8 factors contained in the development of facilities and infrastructure with 16 variables in the western coastal area of the city of Tarakan.
\end{abstract}

\section{Keywords: Coastals, Facilities, Infrastructure, Residence}

\section{PENDAHULUAN}

Kota tarakan memiliki letak yang strategis sebagai kota yang berkembang di wilayah Kalimantan utara, selain itu juga memiliki garis pantai dengan panjang kurang lebih $65 \mathrm{Km}$ mengelilingi pulau Tarakan (Prihartanto and Roem, 2016). Luas Kota Tarakan adalah 657,33 $\mathrm{km} 2 / \mathrm{sq} . \mathrm{km}$ dan Secara astronomis, Kota Tarakan terletak antara $3^{\circ} .14^{\prime} 30^{\prime \prime}-$ $3^{\circ} .26^{\prime} 37^{\prime \prime} \quad$ Lintang Utara dan $117^{\circ} .30^{\prime} 50^{\prime \prime}-117^{\circ} .40^{\prime} 12^{\prime \prime}$ Bujur Timur (Badan Pusat Statistik, 2020).

Menurut definisi, pengembangan wilayah merupakan program yang menyeluruh dan terpadu dari semua kegiatan dengan memperhitungkan sumber daya yang ada dan kontribusinya pada pembangunan suatu wilayah (Adisasmita, 2008). ((Rustiadi, 
Saefulhakim and Panuju, 2011) menyatakan skala prioritas diperlukan dalam suatu perencanaan pembangunan karena keterbatasan sumber daya yang tersedia. Pengembangan wilayah menempatkan pemerintah daerah, masyarakat, dan stakeholder lainnya sebagai subyek utama pembangunan.

Pemanfaatan Ruang Pemanfaatan ruang dilakukan melalui pelaksanaan program pemanfaatan ruang beserta pembiayaannya. Pelaksanaan program pemanfaatan ruang merupakan aktifitas pembangunan, baik yang dilaksanakan oleh pemerintah maupun masyarakat untuk mewujudkan rencana tata ruang. Pemanfaatan ruang dapat dilaksanakan baik pemanfaatan ruang secara vertikal maupun pemanfaatan ruang di dalam bumi. Pemanfaatan ruang mengacu pada fungsi ruang yang ditetapkan dalam rencana tata ruang dilaksanakan dengan mengembangkan penatagunaan tanah, penatagunaan air, penetagunaan udara dan penatagunaan sumber daya alam lain, antara lain adalah penguasaan, penggunaan, dan pemanfaatan tanah, air, udara dan sumber daya alam lain melalui pengaturan yang terkait dengan pemanfaatan tanah, air, udara dan sumber daya alam lain sebagai satu kesatuan system untuk kepentingan masyarakat secara adil (Manaf, 2015).

Fungsi tata ruang kawasan pantai adalah merupakan suatu usaha/upaya yang terpadu untuk melestarikan fungsi daripada kawasan pantai yang meliputi kebijaksanaan

pengembangan, penataan, pemulihan, dan pengendaliannya. Setiap usaha pengelolaan wilayah pesisir, sebelumnya diperlukan perencanaan yang matang dalam mengalokasikan sumber daya alam. Perencanaan dapat diartikan sebagai proses persiapan pembuatan keputusan untuk pelaksanaan sesuai dengan sasaran yang diinginkan (Manaf, 2015). Kebijakan pengembangan wilayah juga dapat dilakukan melalui pengelompokan wilayah. Pengelompokan wilayah merupakan alat untuk menganalisis pengembangan wilayah berdasar keunggulan sektor di wilayah tersebut. Pengelompokan wilayah berdasarkan sektor unggulan wilayah dapat menjadi penentu kebijakan dalam pengembangan suatu wilayah (Fundeanu, 2015).

Wilayah pesisir sangat dekat dengan tepi laut, kemudahan jangkauan antara daratan dan lautan menjadi alternatif untuk bermukim. Dominan mata pencarian pemukim di wilayah pesisir adalah nelayan. Peningkatan permukiman menyebabkan kebutuhan akan sarana dan prasarana tidak dapat ditunda dalam rangka meningkat kualitas hidup masyarakat. Sarana dan prasarana sendiri sebagai penunjang aktivitas manusia sehari-hari dalam mempermudah pergerakan barang dan manusia. Potensi pengembangan ke arah pesisir menjadi prioritas pembangunan mengingat Kota Tarakan merupakan pulau transit dengan transportasi darat dan laut.

Ketersediaan infrastruktur dianggap sebagai prioritas utama pengembangan kawasan pesisir. Kelengkapan infrastruktur disuatu wilayah akan membawa investasi dari luar masuk ke dalam wilayah tersebut. Ketersediaan infrastruktur juga memiliki keterkaitan kebelakang yang lebih tinggi dari pada keterkaitan kedepannya yang berarti ketersediaan infrastruktur lebih mampu mendorong pertumbuhan sector hulu dibandingkan dengan sector hilir sehingga infrsatruktur mempunyai peranan yang penting dalam perkembangan ekonomi wilayah pesisir seperti Selumit Pantai.

\section{METODE PENELITIAN \\ Jenis Penelitian}

Jenis penelitian ini adalah statistika deskriptif dimana data yang digunakan dalam penelitian berupa data primer yang merupakan data dari olahan kuesioner. Kuesioner dilakukan untuk memperoleh persepsi berupa identifikasi sarana dan prasarana oleh responden mengenai pengembangan kawasan pesisir di wilayah Selumit Pantai. Responden terdiri atas beberapa masyarakat Kelurahan Selumit Pantai. Analisis awal berupa hasil validasi dan realibiltas terhadap kuesioner yang digunakan untuk melihat gambaran tingkat perkembangan suatu wilayah 
secara administratif dengan menggunakan kelengkapan sarana dan prasarana (infrastruktur) di wilayah tersebut. Wilayah yang menjadi objek penelitian ini adalah RT. 17, 18, 19, 21, dan 28 di Kelurahan Selumit Pantai dengan jumlah responden 100 orang.

\section{Waktu dan Tempat}

Waktu penelitian pengembangan wilayah pesisir dilaksanakan pada tanggal 04 September 2020 , bertempat di RT 17, 18, 1921 dan 28 Kelurahan Selumit Pantai, Kecamatan Tarakan Tengah, Kota Tarakan.

\section{Populasi dan Sampel}

Populasi adalah wilayah generalisasi yang terdiri dari objek atau subjek yang mempunyai kualitas dan karakteristik tertentu yang ditetapkan oleh peneliti untuk dipelajari dan kemudian ditarik kesimpulannya (Sugiyono, 2017). Sampel adalah bagian dari jumlah dan karakteristik yang dimiliki oleh populasi tersebut sampel yang diambil dari populasi tersebut harus betul-betul representative (mewakili). Ukuran sampel merupakan banyaknya sampel yang akan diambil dari suatu populasi (Sugiyono, 2017).

\section{Metode Pengumpulan Data}

Pengumpulan data dalam penelitian ini dilakukan secara acak untuk memperoleh sampel dari populasi yang dimaksud, agar diperoleh data yang baik maka dipilih dengan penyebaran kuesioner.

\section{Menentukan Validasi dan Reabilitas Data}

- Uji Validasi

Validitas berasal dari kata validity yang mempunyai arti sejauh mana ketepatan dan kecermatan suatu alat ukur dalam melakukan fungsi ukurnya (Azwar, 1986). Suatu skala atau instrumen pengukur dapat dikatakan mempunyai validitas yang tinggi apabila instrumen tersebut menjalankan fungsi ukurnya, atau memberikan hasil ukur yang sesuai dengan maksud dilakukannya pengukuran tersebut. Sedangkan tes yang memiliki validitas rendah akan menghasilkan data yang tidak relevan dengan tujuan pengukuran.
Uji Validitas berguna untuk mengetahui kevalidan atau kesesuaian kuesioner yang digunakan oleh peneliti dalam mengukur dan memperoleh data penelitian dari para responden.

\section{Dasar Pengambilan Uji Validitas Pearson}

Pembagian Nilai $r$ hitung dengan $r$ table: Jika nilai $r$ hitung $>r$ table $=$ valid Jika nilai $r$ hitung $<r$ table $=$ tidak valid

- Uji Reabilitas

Reliabilitas menunjukkan sejauh mana hasil pengukuran dengan alat tersebut dapat dipercaya. Hasil pengukuran harus reliabel dalam artian harus memiliki tingkat konsistensi dan kemantapan (Sumadi, 2004). Untuk menjaga realibilitas dalam penelitian ini adalah dengan menghitung koefisien realibilitas pada alat ukur melalui Cronbach Alpha dengan ketentuan nilai Cronbach Alpha $>0,6$. Suatu instrumen alat ukur dikatakan reliabel dan bisa diproses pada tahap selanjutnya jika nilai Cronbach Alpha > 0,6. Jika instrumen alat ukur memiliki nilai Cronbach Alpha $<0,6$ maka alat ukur tersebut tidak reliabel.

\section{HASIL DAN PEMBAHASAN Proses Identifikasi Sarana dan Prasarana}

Adapun hasil yang telah dilaksanakan adalah survei mengenai sarana dan prasarana yang ada di wilayah Selumit Pantai melalui beberapa proses yang telah dilakukan ada beberapa tahapan sebagai berikut :

- Penentuan Jumlah responden

Dalam menentukan jumlah responden menggunakan rumus Slovin. Rumus Slovin (Yusni dan Santoso, 2017) adalah suatu system matematis yang digunakan untuk menghitung jumlah dari sebuah populasi objek tertentu yang belum diketahui karakteristiknya secara pasti. Rumus Slovin :

$\mathrm{n}=\mathrm{N} /\left(1+\left(\mathrm{N} \times e^{2}\right)\right) \ldots \ldots \ldots \ldots$

Dimana :

$\mathrm{n}=$ number of sample ( jumlah sampel) $\mathrm{N}=$ total population (jumlah seluruh anggota populasi) 
JURNAL BORNEO SAINTEK

Volume 4, Nomor 1, April 2021

e-ISSN 2599-3313

P-ISSN 2615-434X

$\mathrm{e}=$ error tolerance ( toleransi terjadinya galat)

Untuk jumlah warga dalam kelurahan Selumit Pantai berjumlah \pm 16.761 jiwa. Kemudian kami mengambil nilai error tolerance (e) adalah 10\%. Sehingga di dapat :

$\mathrm{n}=\mathrm{N} /\left(1+\left(\mathrm{N} \times e^{2}\right)\right)$

$\mathrm{n}=16.761 /\left(1+\left(16.761 \times 10 \%^{2}\right)\right)$

$\mathrm{n}=99,4069 \approx 100$

Jadi, dari rumus didapat jumlah responden yaitu 100 jiwa.

- Menentukan Validasi dan reabilitas data
Available online at www.jurnal.borneo.ac.id Halaman 01-09

Suatu skala atau instrumen pengukur dapat dikatakan mempunyai validitas yang tinggi apabila instrumen tersebut menjalankan fungsi ukurnya, atau memberikan hasil ukur yang sesuai dengan maksud dilakukannya pengukuran tersebut. Sedangkan tes yang memiliki validitas rendah akan menghasilkan data yang tidak relevan dengan tujuan pengukuran.

Uji Validitas berguna untuk mengetahui kevalidan atau kesesuaian kuesioner yang digunakan oleh peneliti dalam mengukur dan memperoleh data penelitian dari para responden. Tabel Berikut adalah variabel yang dijadikan pernyataan pada kuesioner.

Tabel 1. Variabel Pada Sarana dan Prasarana

\begin{tabular}{|l|l|}
\hline No. & \multicolumn{2}{|c|}{ Variabel } \\
\hline Kondisi Fisik \\
\hline 1 & Kemudahan dalam mendirikan konstruksi bangunan rumah \\
\hline 2 & Kemudahan dalam memperoleh sumber air bersih \\
\hline 3 & Kesuburan Tanah \\
\hline Pemahaman Kebencanaan \\
\hline 4 & Pemahaman risiko bencana \\
\hline 5 & Pemahaman jalur evakuasi \\
\hline 6 & Pelatihan tanggap darurat bencana \\
\hline 7 & Partisipasi masyarakat \\
\hline Sosial Demografi \\
\hline 8 & Keamanan lingkungan tempat tinggal \\
\hline 9 & Kenyamanan \\
\hline 10 & Hubungan Sosial Masyarakat \\
\hline 11 & Adanya hubungan keluarga disekitar lingkungan \\
\hline 12 & Biaya hidup \\
\hline Aksesibilitas \\
\hline 13 & Ketersediaan jaringan jalan \\
\hline 14 & Biaya perjalanan menuju tempat kerja \\
\hline 15 & Ketersediaan Transportasi Publik \\
\hline Prasarana \\
\hline 16 & Ketersediaan jaringan air bersih (PDAM) \\
\hline 17 & Ketersediaan jaringan air limbah \\
\hline 18 & Ketersediaan jaringan drainase \\
\hline 19 & Ketersediaan jaringan listrik \\
\hline 20 & Ketersediaan jaringan komunikasi \\
\hline
\end{tabular}




\begin{tabular}{|l|l|}
\hline \multicolumn{2}{|l|}{ Sarana } \\
\hline 21 & Ketersediaan sarana perdagangan \\
\hline 22 & ketersediaan sarana pendidikan \\
\hline 23 & ketersediaan sarana peribadatan \\
\hline 24 & ketersediaan sarana kesehatan \\
\hline Peluang Ekonomi \\
\hline 25 & Ketersediaan lahan pertanian \\
\hline 26 & Ketersediaan lahan pertambakan \\
\hline 27 & peluang membuka toko \\
\hline 28 & peluang kesempatan kerja \\
\hline 29 & keberadaan indutri \\
\hline Pengembangan Kawasan \\
\hline 30 & Ketersediaan jaringan jalan \\
\hline 31 & Biaya perjalanan menuju tempat kerja \\
\hline 32 & Ketersediaan Transportasi Publik \\
\hline 33 & Harga Tanah \\
\hline Sistem Waris \\
\hline 34 & Kepemilikan Lahan \\
\hline
\end{tabular}

Pembagian Nilai $r$ hitung dengan $r$ table : Jika nilai $r$ hitung $>r$ table $=$ valid Jika nilai $r$ hitung $<r$ table $=$ tidak valid Sebelum mengolah data pada SPSS terlebih dahulu masukkan data. Setelah data yang telah dimasukkan tersebut, selanjutnya adalah memasukkan data untuk diolah ke SPSS untuk mengetahui kevalidan data yang ada, Nilai $r$ table dengan $\mathrm{N}=100$ (untuk nelayan) pada signifikansi $5 \%$ pada distribusi $r$ table statistic, maka diperoleh nilai $r$ table sebesar 0,195. Dan uji Reabilitas untuk Alpha $=0,434$. sehingga didapatkan pada tabel 2 berikut :

Tabel 2. Rekapitulasi Validasi dan Reabilitas

\begin{tabular}{|l|l|}
\hline \multicolumn{2}{|l|}{ Kondisi Fisik } \\
\hline 1 & Kesuburan Tanah \\
\hline Pemahaman Kebencanaan \\
\hline 2 & Pemahaman jalur evakuasi \\
\hline 3 & Pelatihan tanggap darurat bencana \\
\hline 4 & Partisipasi masyarakat \\
\hline Sosial Demografi \\
\hline 5 & Keamanan lingkungan tempat tinggal \\
\hline 6 & Kenyamanan \\
\hline Prasarana \\
\hline 7 & Ketersediaan jaringan air limbah \\
\hline 8 & Ketersediaan jaringan listrik \\
\hline 9 & Ketersediaan jaringan komunikasi \\
\hline Sarana \\
\hline 10 & Ketersediaan sarana perdagangan \\
\hline
\end{tabular}




\begin{tabular}{|l|l|}
\hline 11 & ketersediaan sarana pendidikan \\
\hline Peluang Ekonomi \\
\hline 12 & peluang kesempatan kerja \\
\hline 13 & keberadaan indutri \\
\hline Pengembangan Kawasan \\
\hline 14 & Ketersediaan jaringan jalan \\
\hline 15 & Biaya perjalanan menuju tempat kerja \\
\hline Sistem Waris \\
\hline 16 & Kepemilikan Lahan \\
\hline
\end{tabular}

Dari proses validasi dan reabilitas didapatkan variabel yang akan dijadikan pernyataan pada kuesioner selanjutnya. Cara untuk mendapatkan besaran persentasi pada kriteria dilakukan dengan membagi pernyataan menjadi Variabel - variabel tersebut yang sudah dikelompokkan tiap Variabelnya kemudian dilakukan skoring menggunakan Skala Likert dalam bentuk kuesioner tingkat kepentingan dan dibagikan kepada responden di wilayah penelitian. berdasarkan pernyataan tersebut didapat hasil berupa rekapitulasi dalam bentuk diagram sebagai berikut:

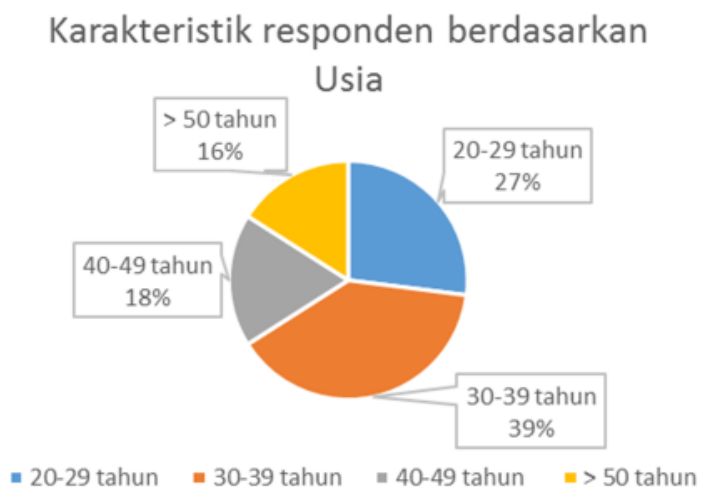

Gambar 1. Usia Responden

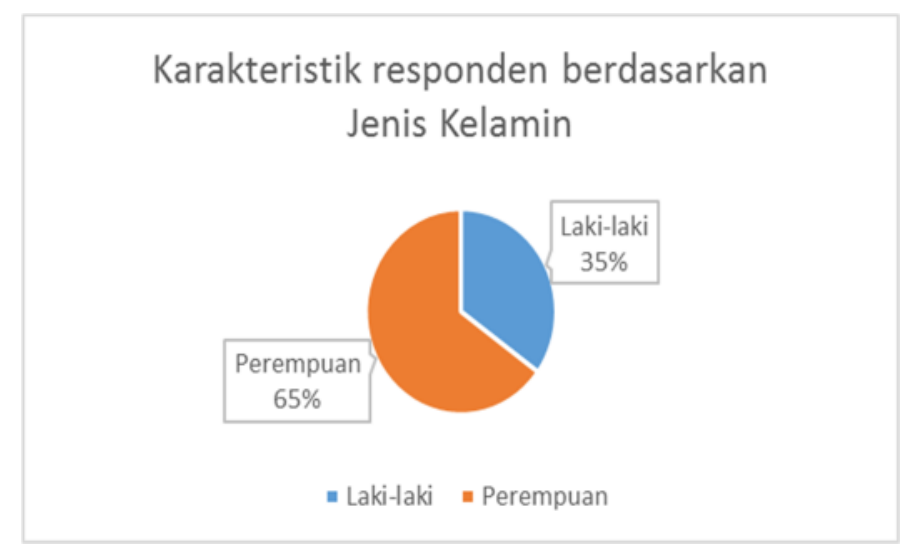

Gambar 2. Jenis Kelamin Responden 
Karakteristik responden berdasarkan Pendidikan Formal

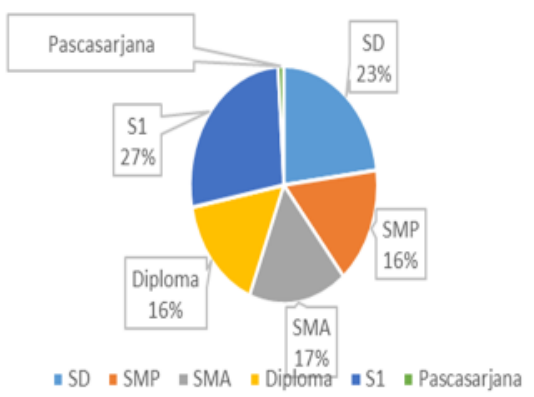

\section{Gambar 2. Pendidikan Responden}

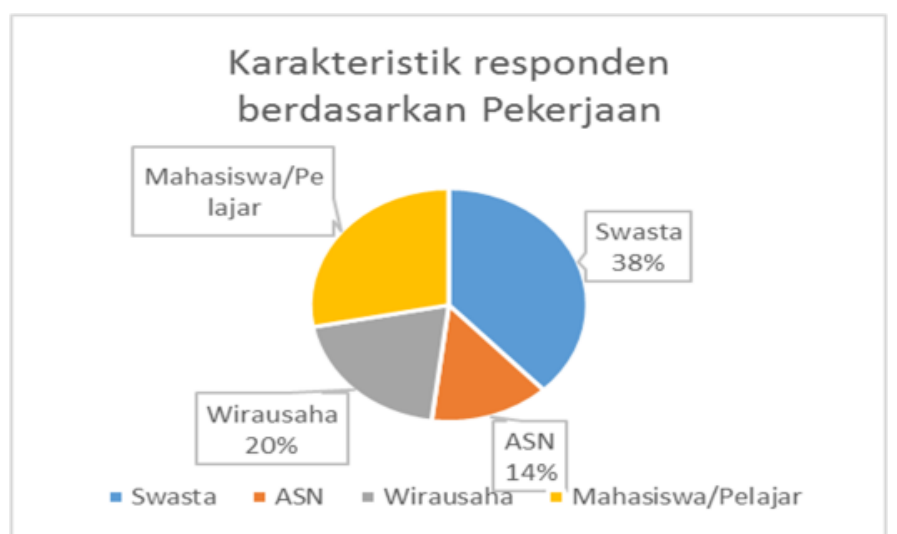

Gambar 4. Pekerjaan Responden

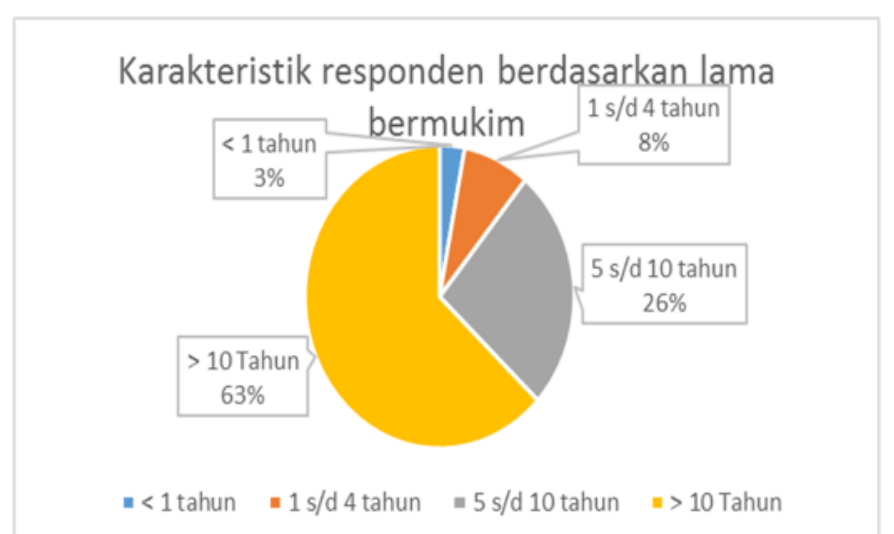

Gambar 5. Lama Bermukin Responden

Tabel 3. Respon Dominan Terhadap Tanggapan

\begin{tabular}{|l|l|l|c|}
\hline No. & \multicolumn{1}{|c|}{ Variabel } & \multicolumn{1}{c|}{ Tanggapan } & \multicolumn{1}{c|}{$\begin{array}{c}\text { Presentasi } \\
\%\end{array}$} \\
\hline Kondisi Fisik & 57 \\
\hline 1 & $\begin{array}{l}\text { Tanggapan Responden tentang Kesuburan } \\
\text { Tanah }\end{array}$ & Tidak Setuju \\
\hline Pemahaman Kebencanaan & 34 \\
\hline 2 & $\begin{array}{l}\text { Tanggapan Responden tentang pemahaman } \\
\text { jalur evakuasi }\end{array}$ & Tidak Setuju & 23 \\
\hline 3 & \begin{tabular}{l} 
Tanggapan Responden tentang pelatihan \\
\hline
\end{tabular}
\end{tabular}




\begin{tabular}{|c|c|c|c|}
\hline & tanggap darurat bencana & & \\
\hline 4 & $\begin{array}{l}\text { Tanggapan Responden tentang Partisipasi } \\
\text { masyarakat }\end{array}$ & Netral & 32 \\
\hline \multicolumn{4}{|c|}{ Sosial-Demografi } \\
\hline 5 & $\begin{array}{l}\text { Tanggapan Responden tentang Keamanan } \\
\text { lingkungan tempat tinggal }\end{array}$ & Sangat tidak Setuju & 26 \\
\hline 6 & Tanggapan Responden tentang Kenyamanan & Sangat Setuju & 32 \\
\hline \multicolumn{4}{|c|}{ Prasarana } \\
\hline 7 & $\begin{array}{l}\text { Tanggapan Responden tentang Ketersediaan } \\
\text { jaringan air limbah }\end{array}$ & Sangat Tidak Setuju & 39 \\
\hline 8 & $\begin{array}{l}\text { Tanggapan Responden tentang ketersediaan } \\
\text { jaringan listrik }\end{array}$ & Sangat Setuju & 56 \\
\hline 9 & $\begin{array}{l}\text { Tanggapan Responden tentang ketersediaan } \\
\text { jaringan komunikasi }\end{array}$ & Setuju & 38 \\
\hline \multicolumn{4}{|c|}{ Sarana } \\
\hline 10 & $\begin{array}{l}\text { Tanggapan Responden tentang tersedianya } \\
\text { sarana perdagangan }\end{array}$ & Tidak Setuju & 32 \\
\hline 11 & $\begin{array}{l}\text { Tanggapan Responden tentang tersedianya } \\
\text { sarana pendidikan }\end{array}$ & Sangat Setuju & 28 \\
\hline \multicolumn{4}{|c|}{ Peluang Ekonomi } \\
\hline 12 & $\begin{array}{l}\text { Tanggapan Responden tentang peluang } \\
\text { kesempatan kerja }\end{array}$ & Tidak Setuju & 36 \\
\hline 13 & $\begin{array}{l}\text { Tanggapan Responden tentang keberadaan } \\
\text { industri }\end{array}$ & Sangat Tidak Setuju & 26 \\
\hline \multicolumn{4}{|c|}{ Pengembangan Kawasan } \\
\hline 14 & $\begin{array}{l}\text { Tanggapan Responden tentang ketersediaan } \\
\text { jaringan jalan }\end{array}$ & Setuju & 24 \\
\hline 15 & $\begin{array}{l}\text { Tanggapan Responden tentang } \\
\text { perjalanan menuju tempat kerja }\end{array}$ & sangat tidak setuju & 38 \\
\hline \multicolumn{4}{|c|}{ Sistem Waris } \\
\hline 16 & $\begin{array}{l}\text { Tanggapan Responden tentang kepemilikan } \\
\text { lahan }\end{array}$ & Sangat Tidak Setuju & 48 \\
\hline
\end{tabular}

Dari tanggapan responden tersebut, diperoleh bahwa kesuburan tanah pada wilayah kelurahan Selumit pantai terhadap kesuburan tanah hanya sebatas tempat bermukim tanpa melakukan aktivitas pertanian. Pemahaman bencana masih tergolong minim dan masih bersifat spontan dalam menanggapi bencana. Keamanan tempat tinggal juga masih diisi dengan respon tidak setuju dikarenakan padatnya permukiman sehingga aktivitas kegiatan masyarakat dari segala lini masih kurang terpantau oleh setiap kepala keluarga setempat dengan adanya permukiman padat tersebut tidak mengurangi tingkat kenyaman dalam bertempat tinggal di kelurahan Selumit Pantai. Prasarana jaringan air bersih, listrik, dan jaringan komunikasi pun sudah dapat dinikmati di wilayah ini. Untuk sarana perdagangan masyarakat secara mandiri membuat kios/warung dirumah sendiri dan untuk sarana pendidikan telah tersedia tempat pembelajaran taman Al Quran yang dirasa telah mencukup. Peluang Ekonomi yang dirasakan responden dalam hal ini peluang kesempatan kerja masih minim, ini dikarenaka disekitar Selumit pantai lebih dominan untuk bermukim daripada untuk daerah Industri dan perkantoran. Pengembangan Kawasan di Wilayah Kelurahan Selumit Pantai masih terus berkembang sejalan dengan kebutuhan masyarakat akan sarana dan prasarana. Untuk sistem waris, disana cenderung keluarga yang berkumpul bersama keluarga besar.

\section{KESIMPULAN}

Variabel dengan tanggapan responden dominan memberikan pandangan deskripsi terhadap pengembangan wilayah terkhusus sarana dan prasarana 
JURNAL BORNEO SAINTEK

Volume 4, Nomor 1, April 2021

e-ISSN 2599-3313

P-ISSN 2615-434X

sebagai wujud majunya suatu wilayah. Dimana pemahaman bencana harus lebih difokuskan mengingat permukiman di wilayah pesisir memiliki potensi bencana tinggi serta Permukiman pesisir lebih dominan untuk hunian tempat tinggal. Dari penelitian ini dapat memperlihatkan bahwa secara sarana dan prasaran di wilayah Kelurahan Selumit Pantai dapat dikatakan telah memadai dan memberikan fasilitas layanan kepada masyarakat setempat.

\section{DAFTAR PUSTAKA}

Adisasmita, R. (2008) Pengembangan Wilayah: Konsep dan Teori. Yogjakarta: Graha Ilmu.

Azwar, S. (1986) Validitas dan Reliabilitas. Jakarta: Rineka Cipta.

Badan Pusat Statistik (2020) Kota tarakan dalam angka. Tarakan: Badan Pusat Statistik.

Fundeanu, D. D. (2015) 'Innovative Regional Cluster, Model of Tourism Development', in Procedia Economics and Finance.

Manaf, M. (2015) 'ANALISIS PEMANFAATAN RUANG DI WILAYAH PESISIR KECAMATAN BONTOHARU
Available online at www.jurnal.borneo.ac.id Halaman 01-09

KABUPATEN KEPULAUAN SALAYAR', Jurnal Perencanaan Wilayah dan Kota Palno Madani, 4(2), pp. 1021.

Prihartanto, E. and Roem, M. (2016) 'KAJIAN POTENSI PENINGKATAN PERMUKIMAN DI KAWASAN PESISIR DAMPAK ABRASI DENGAN PEMANFAATAN INDERAJA (Studi kasus: Pantai wisata Binalatung, Kota Tarakan)', Jurnal Harpodon, 9(2).

Rustiadi, E., Saefulhakim, S. and Panuju, D. . (2011) Perencanaan dan Pengembangan Wilayah. Jakarta: Yayasan Pustaka Obor Indonesia.

Sugiyono (2017) Metode Penelitian Kuantitatif, Kualitatif, dan R\&D. Bandung: CV. Alfabeta.

Sumadi, S. (2004) Psikologi Pendidikan. Jakarta: Raja Grafindo Persada.

Yusni, M. B. and Santoso, E. B. (2017) 'Analisis Faktor - Faktor yang Mempengaruhi Pengembangan Subsektor Perikanan Tangkap di Pesisir Selatan Kabupaten Tulungagung dengan Konsep Pengembangan Ekonomi Lokal', Teknik ITS, 6(2), pp. C552-C556. 